\title{
Új generáció és régi szerepek egy krónikás szemével
}

\section{Társadalmi elitek, királyi hatalom és generációváltás II. Richard idején Thomas Walsingham krónikájában}

\author{
New Generation and Old Roles through a Chronicler's eyes \\ Social Elites, Royal Power and Generation Changes during \\ the Age of Richard II in Thomas Walsingham's Chronicle
}

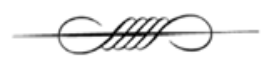

\begin{abstract}
Between 1377 and 1382, not more than in a five year period, series of kings - partly in parallel with them, partly following them - and a remarkable part of the social elite were replaced in the area of Western Europe. This essay focuses on the English changes through the Chronicle of Thomas Walsingham entirely from the death of the Black Prince until the enthronement of Henry IV. Several components can be considered as reasons for the weakening royal power in the age of Richard II: his uncles' influence, the king's personal age and the unsolved social issues all contributed to the decrease of the royal authority. Nevertheless, examining the chronological tables a sharp change in the European generations is noticeable, until the midst of 1380s Walsingham mainly focuses on the religious differences and the effects of the generation change only appears at a higher rate from the second half of the decade. Many times - basing on the text of the chronicle the historian personal point of view appears; in certain descriptions it is externalized to the whole aristocracy to contrast them with the reigning social elite of Edward III's generation.
\end{abstract}

\section{KEYWORDS}

Thomas Walsingham, Richard II, historical narrative, social elite, generation change

DOI 10.14232/belv.2018.2.2 https://doi.org/10.14232/belv.2018.2.2 
Cikkre való hivatkozás / How to cite this article: Bognár, László (2018): Új generáció és régi szerepek egy krónikás szemével: társadalmi elitek, királyi hatalom és generációváltás II. Richard idején Thomas Walsingham krónikájában. Belvedere Meridionale 30. évf. 2. sz. 31-44. pp.

ISSN 1419-0222 (print)

ISSN 2064-5929 (online, pdf)

(Creative Commons) Nevezd meg! - Így add tovább! 4.0 (CC BY-SA 4.0)

(Creative Commons) Attribution-ShareAlike 4.0 International (CC BY-SA 4.0)

www.belvedere-meridionale.hu

A tanulmányban tárgyalt kérdéseket alapvetően egy, a korszakot távolabbról érintő felismerés alapozza meg: az 1377 és 1382 közötti öt éves periódusban számos európai országban történt uralkodóváltás és hozzá kapcsolódóan az elitek részleges vagy közel teljes cseréje zajlott le. ${ }^{1}$ A politikai és társadalmi feszültségek a XIV. század végére oly mértékben kiéleződtek, hogy számos területen komoly válságot idéztek elő. A kronológiai táblázatokat vizsgálva ugyanakkor jogosan tehetjük fel a kérdést: mi történik Európában? Korszakváltás vagy leginkább csupán generációváltás? Az 1377 és 1382 közötti időintervallumban Nyugat-Európa több országában a már évtizedek óta regnáló személyek sora lecserélődött, ami sok esetben a királyi apparátus jelentős megváltozását is jelentette.

A Német-római Birodalom területein történő uralkodóváltás ugyan nem járt különösebb nehézségekkel, de az azt kísérő zavargások már IV. Károly regnálásának végén ismételten felütötték fejüket. Bár I. Venczel német király alig 18 éves volt, mikor apja nyomdokaiba lépett, IV. Károly tapasztalt hivatalnokai a kezdetektől mellette álltak. A XIV. század végén a belső konfliktus legnagyobb szikráját a nemesség és a városok között húzódó viszály okozta. Leginkább a lakosság szenvedte meg a kétoldalú nyomást, aminek eredményeképpen a korszakban gyakoriak voltak a felkelések. ${ }^{2}$

Jól ismert, hogy a pápaság helyzete is gyökeres változásokon ment keresztül a XIV. század végén. XI. Gergely 1376-ban elhagyta Avignont és visszatért Rómába. Utódja, VI. Orbán rossz kapcsolata a bíborosokkal újabb egyházszakadást eredményezett. A kardinálisok érvénytelenítették VI. Orbán kinevezését, majd saját egyházfőtt választottak VII. Kelemen személyében és Avignonba rendezkedtek be ismételten. A korábbiakban is volt példa arra, hogy az uralkodók érdekeik érvényesítésére ellenpápát állítottak az egyházfővel szemben, itt azonban egymástól függetlenül két, külön apparátussal rendelkező egyházi központ alakult ki. Ez az esemény a pápai hatalmat ismételten alapjaiban ásta alá, valamint a keresztény uralkodókat is két táborra osztotta. VI. Orbán Anglia és a német területek támogatását tudhatta maga mögött, míg az Avignonban székelő pápa jó viszonyt ápolt a francia királlyal, az Ibériai-félsziget uralkodóival és Nápollyal. ${ }^{3}$

\footnotetext{
${ }^{1}$ A jelenségre témavezetőm, Gálffy László hívta fel a figyelmemet.

${ }^{2}$ HLAVÁČEK 2008. 558.

${ }^{3}$ LINEHAN 2008. 624-629.
} 
Kasztíliában II. Trastamarai Henrik (1369-1379) fivére, Pedro megölésével szerezte meg a trónt. A polgárháborún túl Henriknek külső fenyegetéssel is szembe kellett néznie I. Ferdinánd portugál király (1367-1383) személyében, aki IV. Sancho örököseként magának követelte a kasztíliai trónt. A vizsgált öt éves időszakban, ezen a területen is uralkodóváltás történt: Henriket fia, I. János (1379-1390) követte a trónon. ${ }^{4}$

V. Károly francia királyt 1380-ban alig 12 éves fia követte a trónon, aki nagybátyjai vetélkedése közepette kezdte meg regnálását. A helyzetet tovább súlyosbította, hogy az új uralkodó mentális állapota a későbbiekben jól érzékelhetően megromlott, és ezzel teljesen kiszolgáltatottá vált apja testvéreinek. Bár formálisan VI. Károly ült a trónon, a tényleges hatalom az előző generációhoz tartozó királyi családból származó hercegek kezében volt, akik saját hatalmi bázissal rendelkeztek. ${ }^{5}$ A lázadások a korszakban megsokasodtak, VI. Károlynak már 1381-ben egy felkeléshullámmal kellett szembenéznie az ismételten kivetett adók miatt. A bel- és külpolitikában is nagy befolyással bíró Anjou Lajos is csupán néhány évvel élte túl V. Károlyt; 1384-ben a Durazzói Károllyal folytatott eredménytelen háborúk után Bari kastélyában halt meg. ${ }^{6}$

A tanulmány az említett váltást Anglia kapcsán kísérli meg bemutatni Thomas Walsingham Chronica Maiora néven nevezetes művére alapozva. A Saint albansi szerzetes munkájának tekintett krónika 1376-tól 1422-ig mutatja be az eseményeket, főként a szigetország történelmére helyezve a hangsúlyt. Az öt éves időszakban történt változásokon túl, fontosnak tartom tárgyalni azok hatásait is, elsősorban a királyi tekintély és az uralkodó családon belüli konfliktusok függvényében. Az elbeszélés elemzésekor a történetíró személyes állásfoglalását keresem, azt vizsgálva, hogy a szövegben II. Richard uralmának (1377-1399) tárgyalásakor hol, és milyen kontextusban jelenik meg egy új periódus, illetve a generációváltás gondolata. Igyekszem továbbá megvilágítani, hogy a korszakban miként látja az angol állapotokat egy, az uralkodó arisztokráciát kívülről szemlélő - ám egyes esetekben közvetetten érintett - krónikás, és szemében milyen veszélyekkel járhat, ha egy gyermekkirály ül trónon.

Angliában III. Edward félévszázados uralma az 1370-es években gyengülés jeleit mutatta. A regnálásának jelentős részét kitevő külhoni sikereket a százéves háború során felváltották a francia győzelmek mind katonai, mind pedig diplomáciai téren. III. Edward örökösének személye is ezekben az években vált kérdésessé. 1368-ban elhunyt második legidősebb fia, Lionel, Clarence hercege. ${ }^{7} 1369$-től kezdve Edward egyre inkább elvonult az államügyektől. A trónörökös, Edward of Woodstock egészségi állapota is sokat romlott, 1370-ben aquitániai hercegségéből is hazatért. A herceg 1376-ban elhunyt, akit apja is követett a következő esztendőben. A trónt végül III. Edward unokája, a korábbi trónörökös fia, az alig 10 éves Richard foglalta el. ${ }^{8}$

George Holmes szerint III. Edward politikájának legfontosabb sarokköve a nemességgel való kivételesen jó viszony volt. A történész ugyanakkor párhuzamot von Anglia helyzetében a hatvanas illetve hetvenes évek között, és az 1376-1381-es periódus bonyodalmait a megosztott hatalomgyakorlásnak tulajdonítja. Az ország belső meggyengülése kutatásai alapján érezhetően

\footnotetext{
${ }^{4}$ O’Callaghan 1994. 524-528.

${ }^{5}$ Autrand 2008. 424-425.

${ }^{6}$ VALOIS 1894. 150.

7 TUCK 1973. 8.

${ }^{8}$ KeEN 2003. 207.
} 
a hetvenes évekre tehető, legfőképpen az Edward halála utáni időszakra. ${ }^{9}$ Walsingham a krónikájában a belső megosztottságot a későbbi évek során tárgyalja, narratívája elején leginkább az ország belső, vallási megosztottságára helyezi a hangsúlyt, és ebben látja az elsődleges megosztó tényezőt. ${ }^{10}$

II. Richard mellé nem neveztek ki régensuralkodót, ${ }^{11}$ így 1381-ig nem volt aktív uralkodója az országnak. II. Richard alakja a mai történészek által sokat tárgyalt téma, személyisége rendkívül összetett, döntései kimeneteléért sok esetben a környezetét tartják felelősnek. A középkori krónikás 1387-ről való feljegyzése szerint is a király személyes köre nem tanítja semmire az ifjú uralkodót. ${ }^{12}$ A belpolitikai feszültségeket tovább növelte, hogy II. Richard nagybátyjai közel sem rendelkeztek akkora befolyással unokaöccsükre, mint az uralkodó közvetlen tanácsadói. Nem hagyhatjuk azonban figyelmen kívül a tényt, hogy tekintélyük az országban egyes esetekben akár a királyéval is vetekedett. ${ }^{13}$

A XIV. század utolsó két évtizedében Angliában jól érzékelhetően megváltozott az ország vezető elitjének összetétele. Az 1381-es parasztfelkelés után a király körül egyre inkább kialakult egy kör, ami rendszerint szemben állt a régi arisztokráciával, föként a korábbi generációhoz és az uralkodó családba tartozó hercegekkel. Az 1386 és 1388 közötti periódus alapjaiban rengette meg az országot, a király végül engedni kényszerült. Uralkodásának végén, 1397 és 1399 között újabb tisztogatás kezdődött meg a nemességen belül, ezúttal II. Richard bosszújának eredményeképpen, rendszerint koholt vádak alapján. Mindezek után egy dinasztiaváltás is következett, amit tovább hangsúlyozott, hogy IV. Henrik háborúi idején is politikailag befolyással bíró személyek sora cserélődött le. ${ }^{14}$

\section{A GYERMEKKIRÁLY}

Walsingham az események ismertetésén túl több esetben maga is kifejti állásfoglalását. A Chronica Maiorában az 1383-ig, szélesebben tárgyalt időszakban II. Richardról meglehetősen kevés szó esik, aminek több oka is lehet. Egyrészt a krónikás föként a vallási kérdések megvitatására koncentrált, St. albansi apát lévén ez érthető. Másrészt a királyról szóló arányaiban kevés elbeszélés azt is sugallhatja, hogy nem a korona birtokosa volt igazán nagy hatással az események kimenetelére. Richardról a krónikás megemlékezései meglehetősen negatív hangvételűek néhány kivételtől eltekintve, melyek valószínűleg Walsingham valamilyen érintettsége miatt tűntek fel a többitől eltérő, pozitív módon.

\footnotetext{
${ }^{9}$ Holmes 1962. 123., 183-184.

${ }^{10}$ CLARK 2005. 26.

${ }^{11}$ John of Gaunt bár kétségtelenül nagy befolyással és vagyonnal rendelkezett a régensszerep betöltésére, az egyházzal és a londoni néppel való rossz viszonya miatt kinevezése nagy ellenzékre talált volna. A londoni nép a néhai Fekete Herceg özvegyével lényegesen jobb kapcsolatot ápolt, de politikai tapasztatlansága valamint neme okán szóba sem kerülhetett ideiglenes uralkodóként. TUCK 1999. 150-151.

${ }^{12}$ Clark 2005. 248.

${ }^{13}$ KeEN 2003. 207.

${ }^{14}$ KEEN 2003. 227-231.
} 
A történetíró számtalan esetben hangsúlyozza a király korát, mint döntéseit elsődlegesen meghatározó tényezőt. 1382-ig Walsingham Richarddal kapcsolatban saját megérzéseit ritkán örökíti meg, akkor is reményteli formában. Egy 1377-es eset kapcsán az uralkodóról ideális királyi képet formál, amikor Richard békét akart teremteni alattvalói között és rendszerint mindkét fél javát nézte a vitás kérdések során. ${ }^{15}$ Jelen esetben a krónikás azért emelhette ki a király békéltető szándékait, mert így véget vetett Sir Peter de la Mare fogságának, akivel a történetíró feltételezhetően baráti viszonyt ápolt. Érthető, ha Walsingham pozitív képet fest az uralkodóról, miután egy valószínűsíthetően közeli ismerőse számára kedvező döntést hozott. ${ }^{16}$ A Chronica Maiora elején a szerzetes az esetek értékelésekor a királyt igazságos szerepben tünteti fel.

Az 1382-ben bekövetkező események kapcsán a történetíró viszont már nyíltan állást foglal II. Richarddal szemben. Walsingham rosszallását az angol királyi pecsét őrének elmozdítása okozta, miután a tisztség viselője nem tett eleget Richard néhány lovagjának földterületszerzéssel kapcsolatos követelésének. A krónikás a terjedelmében rövid leírásban az uralkodóról háromszor jegyzi meg, hogy fiatalsága révén csupán gyermeki szellemmel bír, aki döntéseiben tévedett és saját magát szegényíti el. ${ }^{17}$

A II. Richardról kialakult negatív képnek számos komponense van. Általánosan megfigyelhető, hogy a krónikások meglehetősen hűvös formában emlékeznek meg Richard uralmáról. Optimális esetben a leendő király már apja regnálása idején hírnevet és elismerést szerzett, amellyel megalapozhatta leendő tekintélyét, miként azt apja, a Fekete Hercegként elhíresült trónörökös is tette. Richardnak azonban a családban gyorsan bekövetkező halálesetek és ifjúsága miatt erre nem volt lehetősége.

Thomas Arundel, Canterbury érseke Richard trónfosztásakor beszédet tartott a megbuktatott uralkodóról. Christopher Fletcher kutatásai rámutatnak, hogy az egyházi személy az érvelését a fiatal kormányzat tapasztalatlanságából eredő hibákra építette fel, azt hangoztatva, hogy az embereket nem egy gyermeknek, hanem egy férfinak kell vezetnie. Bár II. Richard és IV. Henrik mindketten 32 évesek voltak, a gondolatmenet a kor embere számára így is meggyőző és hatásos lehetett. Ahogyan ma, feltehetőleg a kortársak is leginkább a fényűző udvari kultúrával kötötték össze II. Richard nevét, olyan embernek tarthatták az uralkodót, aki lehetőség szerint távol tartotta magát a korszakban elvárt lovagi ceremóniákban való részvételtől. ${ }^{18}$

Vivian Hunter Galbraith kutatásai ${ }^{19}$ óta elfogadott nézet, hogy az eseményeket 1376-tól 1422-ig tárgyaló Chronica Maiora egészében Thomas Walsingham műve, ${ }^{20}$ ugyanakkor valószínűsíthető, hogy a történetíró többször átírta krónikáját és a végső verzió meglehetősen Richard-ellenes élt kapott. ${ }^{21}$ A középkori királyok megítélése a krónikákban rendszerint katonai sikereik és az egyházzal való viszonyuk alapján rögzült, de nem elhanyagolható az uralmukat

\footnotetext{
${ }^{15}$ Clark 2005. 36.

${ }^{16}$ CLARK 2005. 6., 36.

${ }^{17}$ CLARK 2005. 186-187.

${ }^{18}$ FLETCHER 2005. 3-5.

${ }^{19}$ Galbraith 1932. 29.

${ }^{20}$ CLARK 2002. 833-834.

${ }^{21}$ Walsinghamről 1420 utánról, nem rendelkezünk információval, de lehetséges, hogy a krónikás még az 1420-as évek végén is életben volt. Ez esetben viszont még az 1422-es eseményeket is lehetett ideje többször újraírni. CLARK 2005.7.
} 
kísérő arisztokrácia hatása sem; és II. Richard esetében különösen fontos az utóbbi tényező. ${ }^{22}$ A kialakult képben minden bizonnyal a dinasztiaváltás is közrejátszott, különösképpen miután IV. Henriknek uralkodáshoz való legitimitásáért folyamatosan küzdenie kellett, így a Lancastereknek érdekükben állt rossz színben feltüntetni elődjüket. További fontos tényező, hogy II. Richard regnálásáról nincs egyetlen királyi szemszögből írt krónika sem. Az uralkodó sem politikai, sem pedig katonai szempontból nem volt sikeres idealizmusa miatt, ugyanakkor impulzív jelleme mellett az érzékenység és az intelligencia is fontos része volt személyiségének. ${ }^{23} \mathrm{John}$ Taylor megállapítása szerint Richard kívül esett az ideális királyképnek a korban általánosan elfogadott formáján; a személyéhez hasonló uralkodói jellem a történetírók számára ismeretlen volt. ${ }^{24}$

\section{Az ÖNJElölt RÉGENS ÉS ANGLIA LEGKIVÁLÓBB EMBERE}

A II. Richardról kialakult képet komolyan befolyásolta két nagybátyja: John of Gaunt és Thomas of Woodstock. Az előbbi politikai befolyása esetenként a királyét is meghaladta, ilyen formában megkérdőjelezve az uralkodó regnáláshoz való alkalmasságát. Utóbbit Walsingham az ország legnépszerübb és legjobb embereként ábrázolja, így érthető, hogy miután Richard konfliktusba került vele, majd ki is végeztette az nagyban hozzájárult a király kedvezőtlen megítéléséhez.

Walsingham krónikájában Richard regnálásának kezdetén Lancaster hercege erősen negatív karakterként jelenik meg, a későbbiekben viszont egyre inkább áldozatként szerepel. Unokaöccse uralmának első éveiben John of Gaunt több esetben valóban az ország vezetőjeként járt el saját és Anglia érdekeit nézve - de nem a király ellen - amihez rendszerint megvoltak a kellő eszközei is, így nem meglepő, hogy tekintélyes tábor alakult ki ellene. Nem hagyhatjuk figyelmen kívül a tényt, hogy az ország számára már II. Richard uralkodása előtt is szükség volt egy olyan személyre, aki a királyság ügyeit megfelelő érzékkel átlátja és szükség esetén az irányítása alá vonja. Már az 1370-es évek elején III. Edward és a trónörökös herceg egyre kevésbé politizált, így John of Gaunt a parlamentben gyakran apja és idősebb fivére helyett elnökölt. ${ }^{25} \mathrm{Az}$ eseményeket lejegyző Walsingham egy 1380-as vita kapcsán megjegyzi, hogy a herceg azt tehetett, amit csak kívánt, miként már apja utolsó napjaiban is. Úgy látszik mivel II. Richard mellé nem neveztek ki régensuralkodót, John of Gaunt önkényesen magát léptette elő a tisztségre és ekképpen járt el több eset kapcsán. ${ }^{26}$

A herceg tekintélyét és a királyi hatalom hanyatlását az ország védelmének ellátása is mutatta. 1378-ban az uralkodónak szánt pénzt a herceg a maga javára szavaztatta meg, azért, hogy az angol

\footnotetext{
${ }^{22}$ Goodman - Gillespie 1999. 20.

${ }^{23}$ Ezen személyiségjegyeire jó példa lehet az Anna királyné temetésén történt incidens, amikor a király nyilvánosan megütötte Arundel earljét. Walsingham az esetet a westminsteri apátság beszennyezéseként értékeli. A későbbiekben II. Richard bosszúhadjáratához - a korábban vele szembenálló nemesek ellen - valószínűleg hozzájárult az is, hogy a gyászoló uralkodót lelkileg különösen megviselte fiatal feleségének elvesztése, és érzelmileg még inkább ingataggá vált. CLARK 2005. 292.

${ }^{24}$ Goodman - GillesPie 1999. 16-18., 21.

${ }^{25}$ KeEN 2003. 207.

${ }^{26}$ CLARK 2005. 104.
} 
partokat az összegből egy esztendeig védhesse. Ez az eset ismételten eltért a megszokottól, hiszen az ehhez hasonló nagyszabású, egész ország területét érintő katonai akció rendszerint a király felügyelete alatt történt. ${ }^{27}$

John of Gaunt bár nem rendelkezett sem komoly katonai, sem pedig politikai tapasztalattal - ebből kifolyólag komolyabb háborús eredményt sem tudott felmutatni - mégis kialakult egyfajta kultusza, mintha valóban ő uralkodna az országban. Az 1381-es lázadás során az Essexben gyülekező parasztok a zarándokok útját állták és feleskették őket Richardra, valamint arra, hogy ne fogadják el uralkodói főségét János királynak. A tömegek a herceggel szemben mély ellenérzéseket tápláltak, kastélyát példát statuálva felgyújtották, ugyanakkor az efféle eskütételekre való kötelezés azt jelentheti, hogy Richard valóban híján volt a támogatóknak és az uralmát elismerőknek. ${ }^{28}$

Míg III. Edward kifejezetten jó kapcsolatot ápolt a nemességgel, ami biztos hatalmi bázist nyújtott számára, ${ }^{29}$ addig II. Richard körül kialakult egy személyes kör, akik hatalmukat féltve rendszerint szembehelyezkedtek Lancaster hercegének akaratával, konfliktust generálva ezzel. Az 1384-es Salisbury parlament idején a történetíró nagy hangsúlyt fektet az egyik ilyen ellentét bemutatására. John Latimer, egy karmelita szerzetes a királynak átnyújtott egy dokumentumot, amely szerint John of Gaunt magának szándékozta megszerezni a koronát. Walsingham leírásában az egyházi személy még Krisztus testének szentségére is felesküdött, ezzel is nyomatékosítva, hogy az írásban foglaltak igazak és azt tanácsolta az uralkodónak, hogy semmiképpen se fogadja el a herceg kifogásait mentségül. John of Gaunt érveinek eredményeként azonban a barátot őrizet alá helyezték, de a szerzetes kihallgatására nem került sor, ugyanis két lovag különös kegyetlenséggel megölte. Walsingham az esemény leírásában nem gyanúsítja meg a herceget a szerzetes ily módon történő elhallgattatásával - noha másnak nem álhatott érdekében inkább azt tartja különösen elborzasztónak, hogy a kínzást lovagok végezték. ${ }^{30}$ A történetíró állásfoglalásának több oka is lehet. Valószínű, hogy ő maga is félt vagy pedig elképzelhető, hogy szimpátiát kezdett érezni a herceg iránt, aki rendszerint a Richardot támogató elit összeesküvéseinek elsőszámú célpontja volt.

A példa azt mutatja, hogy II. Richardnak nem sok befolyása volt az események kimenetelére, hiszen az örizete alatt álló koronatanút is megölték. A herceg védelmében Sir Thomas Woodstock, Buckingham earlje berontott a trónterembe, majd nyilvánosan megfogadta, hogy megöli azt, aki fivérét, John of Gauntot megvádolja, ezzel nyíltan megfenyegetve az uralkodót is. Richard nem mert semmit reagálni, amit Walsingham a királyi hatalom gyengeségének tulajdonít. Megfogalmazása szerint ,, Sir Thomas viselkedése fóbenjáró bün lett volna, ha a király megfelelően kezében tartotta volna az országát. " ${ }^{11}$ Maga a tény, hogy egy, a király őrizetében álló koronatanút kivégeztek, különösen rossz fényt vet Richard hatalmának megítélésére. Eszerint

\footnotetext{
${ }^{27}$ CLARK 2005. 63.

${ }^{28}$ CLARK 2005. 121., 123.

${ }^{29}$ Bothwell 2004. 156.

${ }^{30}$ Egy kötélen fellógatták a szerzetest nyakánál és genitáliáinál, hasára pedig egy nehéz sziklát helyeztek, aminek következtében megfulladt és gerince eltört. CLARK 2005. 215-217.

${ }^{31}$ Clark 2005. 217.
} 
Lancaster hercege befolyással bírt az uralkodó közvetlen környezetében is, máskülönben nem valószínűsíthető, hogy Latimert a lovagok kezére tudta volna juttatni. ${ }^{32}$

A lovagokkal kapcsolatban a történetíró munkájában több esetben megjelenik az erkölcstelenség és a kötelezettségek elmulasztásának kritikája. Egy 1383-as esetet illetően a flandriai harcokban a krónikás megítélése szerint jó esély kínálkozott a francia királlyal való megütközésre és legyőzésére, mikor VI. Károly ostrom alá vett egy angolok által védett várost. Az ostromlottak nem kaptak Angliából segítséget, így végül feladni kényszerültek az erődítményt. Walsingham negatívan emlékezik meg a nemesség hozzáállásáról és a király „,hirtelen” békevágyáról, sugallva elégedetlenségét a kontinensen harcoló katonák cserbenhagyásával kapcsolatban. A történetíró a leírás időpontjához viszonyított múltbéli tetteket komoly erkölcsi tartalommal tölti fel, míg az akkori attitűdöt komoly kritikával illeti. Bár Walsingham nem részletezi, hogy mely diadalokra és hőstettekre gondolt a párhuzamban, de figyelembe véve a százéves háború angolok számára gyümölcsöző éveit, a III. Edwardról és legidősebb fiáról való leírásokat valószínűsíthető, hogy a történetíró rájuk asszociált a sikerek kapcsán. ${ }^{33} \mathrm{~A}$ hadjáratban több egyházi személy is részt vett, így lehetséges, hogy a krónikás közeli ismerősei is elestek, ezért számára a kudarc személyes veszteségekkel is járhatott, ami befolyásolhatta az események elbeszélésében. ${ }^{34}$

Walsingham a nemesség egy részét érintően már III. Edward idejéről is lejegyzett egy esetet. 1376-ban a parlamentben Peter de la Mare nyilvánosan felszólalt az uralkodó szeretője és a királyi tanács néhány tagja ellen. A krónikás a szónokot azon túl, hogy az összes lovag képviselőjének nevezi, retorikai és szellemi adottságait is hosszasan dicséri. ${ }^{35}$ Ebből a leírásból is látszik, hogy bár III. Edward példásan jó viszonyt ápolt a nemességgel, élete utolsó éveiben szeretőjétől való függősége miatt megítélése megromlott és ez megjelenik Walsinghamnél is. ${ }^{36}$

Bár a történetíró a nemességet - különösképpen az 1380-as évek végéig - rendszerint negatívan értékeli, az évtized első fele John of Gaunt megítélésében fordulópontot hozott. A herceg viszonya a valláshoz több esetben is megkérdőjeleződött az 1370-es évek végén. Gauntot többször meggyanúsították azzal, hogy nem csak szimpatizált a lollardizmussal, de támogatta is Wycliffe tanait. Az 1380-as évek elejére azonban a herceg karmelita hatásra egyre inkább elidegenedett az eretneknek ítélt tanoktól, továbbá 1383-ban felhatalmazást kapott VI. Orbántól egy keresztes hadjárat vezetésére Kasztíliába. Ezeknek a folyamatoknak az eredményei kétségkívül szimpátiát ébreszthettek a korábban ellenséges krónikásban, hiszen mint narratívája súlypontjai is mutatják, ezekben az években számára a római pápai szupremácia és a lollard tanítások elvetése különös jelentőséggel bírtak. Az 1380-as évektől kezdve Gaunt egyre inkább az udvari összeesküvések áldozataként jelenik meg Walsinghamnél. ${ }^{37}$

1385-ben Angliát ismételten polgárháború veszélye fenyegette. A király személyes környezetében álló, főként fiatalokból álló kör halálra akarta ítélni Lancaster hercegét, aminek

\footnotetext{
${ }^{32}$ Clark 2005. 217.

${ }^{33}$ ClARK 2005. 209-210.

${ }^{34}$ WRONG 1892. 61.

${ }^{35}$ Clark 2005. 26.

${ }^{36}$ Mortimer 2008. 369-370.

${ }^{37}$ Anthony Goodman 1376 és 1381 közé helyezi a Gauntról való hűvös, már-már ellenséges leírások idejét. GooDMAN 1992. 241-242., 260-261.
} 
eredményeképpen John of Gaunt Pontefract várába vonult, megerősítve harcállásait fegyverés élelmiszerkészletekkel. Walsingham Richard és John of Gaunt vetélkedését nem kizárólag egyfajta személyes ellentétként írja le, hanem gyülöletként, amely egyre nyíltabb formában jelent meg. A krónikás egy esetleges belső anarchia képét vázolja fel amennyiben a király és a herceg viszonya nem javul, hiszen rajtuk kívül - meglátása szerint - senki nem rendelkezett kellő hatalommal a tömegek féken tartásához. ${ }^{38}$

Míg az 1380-as évek közepéig John of Gaunt, addig onnantól Thomas of Woodstock jelenik meg jelentős politikai tényezőként a történetíró munkájában. Ennek fő oka az lehetett, hogy Lancaster hercege az évtized közepén kevesebbet tartózkodott az országban, a II. Richarddal és a hozzá közel álló politikai elittel szemben pedig a nemesek Gloucester hercege mögé sorakoztak fel. Thomas of Woodstock és az uralkodó konfliktusának fő okát Robert de Vere frigyének felbontása Philippa de Couchyval jelentette, amit Richard is támogatott, annak ellenére, hogy a nő a királyi családhoz tartozott. A konfliktus elhatalmasodásának hatásaként Walsingham - a korábban már kialakult gyenge uralkodói kép mellett - egy igazságtalan királyt ábrázol. Robert de Vere veresége után Thomas of Woodstock kezébe kerültek II. Richard levelei, melyben az uralkodó az ellene fellépő nemeseknek biztonságot nyújtó ígéretét megszegve parancsot adott szövetségesének seregei felvonultatására London közelében. A történetírónál az eset kapcsán a levelek Richard megbízhatatlanságának egyértelmű bizonyítékaként tünnek fel a lordok szemében. Walsingham egyetért a Richard nagybátyja mögött felsorakozó arisztokratákkal, ugyanis a konfliktus leírásakor Gloucester táborára végig lordokként hivatkozik, míg Richard követőit rendszerint árulónak nevezte. ${ }^{39}$ A történetíró egyre ellenségesebbé vált II. Richard uralmával kapcsolatban, ahogyan az egyre inkább abszolút jelleget öltött. ${ }^{40}$

\section{BALJÓS ELŐJELEK ÉS IDEALIZÁLT URALKODÓKÉPEK}

Walsingham krónikájában különböző formát ölt a II. Richard, a III. Edward és az ifjabb Edward of Woodstock haláláról szóló megemlékezés. A trónörökösről kifejezetten emelkedett stílusban ír a történetíró, apja esetében már sokkal árnyaltabban, II. Richardról szólva pedig voltaképpen csak megemlíti halálát. Miután a herceg elhunyt, a krónikás teljhatalmú, kül- és belpolitikai sikerekben gazdag uralkodóként festette le. Valószínűleg ebben nagy jelentősége van annak, hogy a trónörökös a lollard tanokat elvetetette, valamint vallásosságának, ami a korszak mércéjével mérve is kiemelkedő. ${ }^{41}$ A leírásban nem szerepel semmiféle negatív utalás, kizárólag a háborús diadalokat említi meg a krónikás, az azokkal járó veszteségeket nem, tartalmában sok hasonlóságot mutat a 21 évvel később elhunyt Gloucester hercegének ábrázolásával. ${ }^{42}$

A két királyról való megemlékezés összehasonlításában több tényezőt is figyelembe kell vennünk. Walsingham a későbbiekben Chronica Maioraként ismert szövegkorpuszt az 1376-os év

\footnotetext{
${ }^{38}$ CLARK 2005. 225-226.

${ }^{39}$ Clark 2005. 255., 258.

${ }^{40}$ STOW 1984. 83.

${ }^{41}$ BARber 1978. 234., 240.

${ }^{42}$ Clark 2005. 27.
} 
eseményeinek leírásával kezdte, tehát Edward regnálásból bő egy évet ${ }^{43}$ jegyzett le, uralkodásának korábbi időszakát pedig főként gyermekként tapasztalhatta meg vagy szájhagyomány útján hallhatott róla ${ }^{44}$ Ezzel szemben Richard országlásának teljes egészét átélte, így komplexebb képet alkothatott. A történetíró szinte élete egészét St. Albansban töltötte, ennek következményeként az események jelentős részéről csak az apátságba látogatóktól hallhatott, ugyanakkor lehettek személyes benyomásai is a királyról. John Taylor kutatásai szerint Richard az 1381-es lázadás után és 1383-ban is járt St. Albansban, valamint 1400 februárjában a holtteste is az apátságban nyugodott a Langley-be tartó gyászmenet idején. ${ }^{45}$

A két uralkodó regnálása is teljesen különböző körülmények között zárult le; míg Edward természetes úton halálozott el, addig Richard a későközépkori Anglia történetében már a második király volt, aki trónfosztva halt meg, a körülményekről pedig több korabeli álláspont is létezett. A két uralkodóváltás között további jelentős különbség, hogy míg III. Edward után kimaradt egy nemzedék a regnálásból és unokája követte, addig fiai közül többen komoly befolyással rendelkeztek; ezzel ellentétben II. Richard trónfosztása után ugyanaz a generáció maradt a trónon, de történt egy dinasztiaváltás.

Walsingham leírásában III. Edward búcsúztatásaként az uralkodó jellemének minél objektívabb ábrázolására törekedhetett. A történetíró a király legnagyobb vétkét a testiség iránti túlzott vágyaiban látta, melynek elsődleges megtestesítője Alice Perrers volt, aki meglehetősen negatív karakterként jelenik meg a narratívában. A krónikás ugyanakkor drámai keretet formált az uralkodó utolsó perceinek leírásához, ezzel egy magányos királyt ábrázolva. Walsingham a király kicsapongó szexuális életét ellensúlyozva rendkívül sok pozitív tulajdonságot helyez a mérleg másik oldalára: Edward anyagiakban mértékletes és nem nagyravágyó vezetőként tűnik fel. Feltételezhetően az ideális királyi tükör megformálásában annak is nagy szerepe volt, hogy egy 50 éves, stabilnak értékelhető korszak zárult le a szigetország történetében. ${ }^{46}$

III. Edwardra már középkorú évei alatt is megváltóként tekintettek, Salamonhoz, Dávidhoz, Arthur királyhoz és Nagy Károlyhoz hasonlítva őt, aki visszaállítja Anglia nagyságát. A kialakult pozitív képen az 1370-es évek sikertelenségei sem sokat rontottak. A király vallásossága a későbbi századokban is példaértékủ volt az angolok számára, ez a fajta keresztény erény minden bizonnyal fontos eleme annak a pozitív képnek miként a krónikások emlékeznek Edwardra. ${ }^{47}$

Richard uralmának vége Walsinghamnél leginkább tényszerü leírásokban jelenik meg, nem pedig a krónikás személyes álláspontjának fejtegetésében. A történetíró Richardról alkotott véleményét ugyanakkor jól illusztrálják a huszonkét évi regnálás fentebb említett epizódja is. Az 1399-es évi részektől kezdve Walsingham mintha szándékosan eltávolodna saját megjegyzéseitől. A korábbiaktól szintén eltérő stílusváltás akkor jelenik meg a történetíró munkájában, mikor IV. Henrik hatalomátvételéről emlékezik meg. A király saját eskütételének idézésén túl a krónikás maga nem

\footnotetext{
${ }^{43}$ Walsingham krónikáját a „,The Good” parlament eseményeinek elbeszélésével kezdi 1376 májusában (a parlament ülésidőszaka április 28-án kezdődött). III. Edward 1377. június 21-én hunyt el. ClarK 2005. 25., 34.

${ }^{44}$ Walsingham 1340 körül született. CLARK 2005. 5.

${ }^{45}$ Goodman - GillesPie 1999. 32.

${ }^{46}$ Clark 2005. 32-33.

${ }^{47}$ ORMROD 1989. 849.
} 
használta az események bemutatásában a korábban alkalmazott megszokott retorikai elemeket, hanem kizárólag a történések egymás utáni leírására koncentrált. ${ }^{48}$

Bár Walsingham röviden emlékezett meg II. Richardról annak elhunytát követően, a király regnálása idején történt konfliktusokat, majd az 1397 és 1399 közötti eseményeket jóval korábbi drámai történések leírásával vezette fel már egészen Richard uralkodásának kezdetétől. A krónikás isteni csapástól retteg, és beteljesedni vél egy jóslatot, amikor Robert Hawleyt a westminsteri apátságban fegyveresek egy csoportja - Richard megsértésére hivatkozva kegyetlen módon megölte egy segítségére siető egyházival egyetemben. Az a szájhagyomány járta, hogy Isten megbosszulja Becket Tamás halálát, amint vér festi vörösre a Westminster szentélyét. A gyilkosságok elkövetőit a történetíró az Antikrisztus előfutárainak tekinti, a meggyalázott templom és Canterbury mártírjának emléke miatt egy prófécia eljövetelét vetíti előre. ${ }^{49}$

Feltűnő az is, amint Walsingham reményteli képet ábrázol Luxemburgi Anna hercegnő ${ }^{50}$ érkezéséről, valamint, arról hogy az összegyült emberek pozitív isteni ómennek tekintették Richard és Anna jövendőbeli házasságát. Miután azonban a vendégek elhagyták a hajókat, a krónikás rég nem látott méretű viharról számol be, ami elpusztította a hercegnőt kísérő flotta nagy részét. A kikötőben történtek után Richard jegyesének érkezését már többen egy negatív előjelnek tekintették, a királyságot érintő szerencsétlen fordulatot jelezve előre. ${ }^{51} \mathrm{~A}$ hercegnővel szemben kialakuló ellenszenvben nagy szerepe lehetett nagyszámú cseh kíséretének is. Az 1381-es események után a zavaros belpolitikai viszonyok és a gazdasági problémák önmagukban is bizonytalansággal tölthették el a kor emberét. Az Annával érkező új politikai elit pedig újabb kételyeket kelthetett a rivalizáló nemesek és a nép körében egyaránt, hiszen az amúgy is sokasodó hatalmi harcokban újabb szereplők jelenhettek meg, ráadásul eltartásuk is anyagilag megterhelö lehetett. ${ }^{52}$

1397-ben miután Richard parancsot adott Arundel earljének kivégzésére, Walsingham egy újabb, a középkori ember számára intő jelet írt le narratívájában. A leírás alapján az earl szelleme visszatért és a királyt még álmában is kísértette. Az uralkodó annyira elbizonytalanodott a rá nehezedő nyomás eredményeként, hogy kiásatta a holttestet, hogy meggyőződjön arról, hogy a fej bizonyosan nem kapcsolódott-e vissza az earl testéhez. ${ }^{53}$ A morális hanyatlás felemlegetése, a holtak világának visszatérése, valamint Richard félelmének ábrázolása egyaránt utal a király bizonytalanságára és az egyre inkább elhatalmasodó paranoiájára.

A krónikás az uralkodók jellemrajzainál a leírások mélységével III. Edwardot sokkal közelebbinek és közvetlenebbnek ábrázolja, mint II. Richardot azáltal, hogy Edward esetében sorokat szentel a király angyalihoz hasonlított arcának és a solymászat, valamint a vadászat iránti szenvedélyének. A történetíró ábrázolásában III. Edward és elsőszülött fia esetében erős jellemábrázolás látható, ezzel szemben Richard lényegesen kevesebb figyelmet kap.

\footnotetext{
${ }^{48}$ Clark 2005. 304-318.

${ }^{49}$ Clark 2005. 69-71.

${ }^{50}$ I. Venczel német király testvére.

${ }^{51}$ Clark 2005. 170-171.

${ }^{52}$ SAUL 2005. 145.

${ }^{53}$ Clark 2005. 300-301.
} 


\section{KONKLÚZIÓ}

Az 1377 és 1382 között lezajló uralkodóváltások Nyugat-Európában számos ponton éreztették hatásukat. A krónikás művének első felében többnyire a keresztény egységre és az 1381-es felkelésben résztvevő tömegek okozta anarchiára és az ezekből származó aggodalmaira koncentrált. Walsinghamet olvasva a generációváltás és II. Richard összetett személyiségének negatív hatásai csupán az 1380-as évek közepétől lettek hangsúlyosak. Erről az időszakról a korábbiakhoz képest arányaiban lényegesen kevesebb egyháztörténeti kérdés kerül előtérbe, amelynek egyik fő oka John Wycliffe 1384-ben bekövetkező halála lehetett. Walsingham krónikájában a belpolitikai viszonyokat tekintve nem érezhető erős váltás közvetlenül III. Edward halála után, valószínüleg a már 1376-ban is betöltetlen politikai vezető szerepkör miatt. A külpolitikai és háborús eredményeket tekintve a krónikás azonban nyíltan állást foglal a régi és az új arisztokrácia katonai és morális szempontból való összehasonlításában és érezhetően a III. Edward kori elit vezetését értékeli pozitívabban. A belpolitikai konfliktusokról való narratívák leginkább az évtized közepétől hangsúlyosak. Walsingham bizalmának első komolyabb törése a király irányában az 1380-as évek közepén történt. Először II. Richard királyi alkalmassága kérdőjeleződött meg a krónikásnál John of Gaunttal szemben az 1384-as év kapcsán; majd pedig az igazságos uralkodóképben alakult ki egy, a történetíró szemében visszafordíthatatlan negatív fordulat a Gloucester hercegével való ellenségeskedés eredményeként.

Ahhoz, hogy Richardot és a regnálásához köthető generációváltást minél objektívabban vizsgálhassuk, számtalan szempontot kell figyelembe vennünk. Elődje, III. Edward uralkodásának jelentős részében hódító királyként vezette Angliát, Richard nem rendelkezett efféle sikerekkel. Az összehasonlítások ugyanakkor különösképpen kézenfekvőek, ha két egymást követő uralkodóról van szó. A konfliktusok leírását vizsgálva feltűnő, hogy az ország népe több esetben - ide értve a király tekintélyének megkérdőjelezését és kigúnyolását - az ifjú uralkodótól türelmetlenül várta, hogy ideje korán felnőjön, és kellő körültekintéssel kezelje az ország ügyeit. Lehetséges, hogy az uralkodóváltás azért is járt ennyi konfliktussal mert az ország népe elszokott a változásoktól és azok hatásaitól. Edward fél évszádos, stabilnak értékelhető regnálását a vezető személyek nagyarányú lecserélődése is követte. Az országlásból ugyanakkor kimaradt egy nemzedék, hiszen a trónörökös Fekete Herceget nem egy fivére, hanem fia, az előző király unokája követte. Ezzel szemben a korábbi generáció - különösképpen Thomas of Woodstock és John of Gaunt - kellő befolyással rendelkezett, ami nem a királyi hatalom megszilárdítását, hanem annak meggyengítését okozta, amiért az uralkodó egyre inkább kizárólag személyes körére támaszkodott.

Richard utódai legitimitásuk igazolása érdekében elődjüket gyenge uralkodóként tüntették fel, hogy saját alkalmasságukat minél inkább kihangsúlyozzák. III. Edward és V. Henrik hódító királyként, a hit és az egyház védelmezőiként jelennek meg. Figyelembe véve az ország helyzetének szempontjából a II. Richard regnálása előtti éveket és V. Henrik hódításokban eredményes uralkodását - ami után néhány évvel hunyhatott el a krónikás - nem meglepő, hogy II. Richard kedvezőtlen szerepben tünik fel a Chronica Maioraban. A király politikai valóságérzetének hiánya és a franciaországi háborúk megszünését célzó békevágya miatt a narratívában háttérbe szorul személyiségének pozitív oldala. 


\section{FELHASZnÁLt IRODALOM}

\section{Forrás}

Clark, James G. (ed.) (2005): The Chronica Maiora of Thomas Walsingham 1376-1422. Woodbridge, The Boydell Press.

\section{Szakirodalom}

Autrand, Françoise (2008): France: France under Charles V and Charles VI. In Jones, Michael (ed.): The New Cambridge Medieval History - volume VI. c.1300-c.1415. Cambridge, Cambridge University Press. 422-441.

Barber, Richard (1996): Edward, Prince of Wales and Aquitaine. Woodbridge, The Boydell Press.

Bothwell, J. S. (2004): Edward III and the English Peerage: Royal Patronage, Social Mobility and Political Control in Fourteenth Century England. Woodbridge, The Boydell Press.

Goodman, Anthony - Gillespie, James L. (ed.) (1999): Richard II: The Art of Kingship. Oxford, Oxford University Press.

Goodman, Anthony (1992): John of Gaunt: The Exercice of Princely Power in FourteenthCentury Europe. Singapore, Longman.

HLAVÁČEK, IvAn (2008): The Empire: The Luxemburgs and Rupert of the Palatinate. In Jones, Michael (ed.): The New Cambridge Medieval History - volume VI. c.1300-c.1415. Cambridge, Cambridge University Press. 551-569.

Holmes, George (1962): The Later Middle Ages 1272-1485. Edinburgh, Thomas Nelson and Sons Ltd.

Keen, Maurice H. (2003): England in the Later Middle Ages. Oxford, Routledge.

Linehan, Peter (2008): The Iberian Peninsula: Castile, Navarre and Portugal. In Jones, Michael (ed.): The New Cambridge Medieval History - volume VI. c.1300-c.1415. Cambridge, Cambridge University Press. 619-652.

Mortimer, Ian (2008): The Perfect King: The Life of Edward III, Father of the English Nation. London, Vintage Books.

O'Callaghan, Joseph F. (1994): A History of Medieval Spain. London, Cornell University Press. Saul, Nigel (2005): The Three Richards: Richard I, Richard II and Richard III. London, Hambledon Continuum.

Tuck, Anthony (1973): Richard II and the English Nobility. London, Edward Arnold Ltd.

Tuck, ANTHONy (1999): Crown and Nobility England 1272-1461. Oxford, Blackwell Publishers Ltd. Wrong, George M. (1892): The Crusade of MCCCLXXXIII., known as that of the bishop of Norwich. London, James Parker and Co. 


\section{Tanulmányok}

Clark, JAMES G. (2002): Thomas Walsingham Reconsidered: Books and Learning at Late-Medieval St. Albans. Speculum vol. 77. no. 3. 832-860.

FletCher, CRISTOPHER (2005): Manhood and politics in the reign of Richard II. Past \& Present vol. 189. no. $113-39$.

Galbraith, Vivian H. (1932): Thomas Walsingham and the Saint Albans Chronicle, 1272-1422. The English Historical Review. vol. 185. no. 1. 12-30.

Ormrod, W. M. (1989): The Personal Religion of Edward III. Speculum. vol. 64. no. 4. 849-877.

Stow, George B. (1984): Richard II in Thomas Walsingham's Chronicles. Speculum. vol. 59. no.1. 68-102.

VAlois, Noel (1894): L'expedition et la mort de Louis $1^{\text {er }}$ d'Anjou en Italie (1382-1384). Revue des questions historiques vol. 28. no. 1. 84-153. 